\title{
Methylation of tumor suppressor genes in ovarian cancer
}

\author{
FILIZ OZDEMIR $^{1}$, JULIDE ALTINISIK $^{1}$, ATES KARATEKE $^{2}$, HAKAN COKSUER $^{2}$ and NUR BUYRU ${ }^{1}$ \\ ${ }^{1}$ Department of Medical Biology, Istanbul University, Cerrahpasa Medical Faculty; \\ ${ }^{2}$ Department of Gynecology and Obstetrics, Zeynep Kamil Maternity and \\ Child Research and Training Hospital, Istanbul, Turkey
}

Received March 23, 2012; Accepted August 9, 2012

DOI: $10.3892 / \mathrm{etm} .2012 .715$

\begin{abstract}
Aberrant methylation of gene promoter regions is one of the mechanisms for inactivation of tumor suppressor genes in human malignancies. In this study, the methylation pattern of 24 tumor suppressor genes was analyzed in 75 samples of ovarian cancer using the methylation-specific multiplex ligation-dependent probe amplification (MS-MLPA) assay. Of the 24 tumor suppressor genes examined, aberrant methylation was observed in 17 . The three most frequently methylated genes were CDKN2B, CDH13 and RASSF1, followed by ESR1 and MLH1. Methylation frequencies ranged from $1.3 \%$ for CDKN2A, RAR $\beta$, CASP8, VHL and TP73 to $24 \%$ for CDKN2B. The corresponding normal DNA from each patient was also investigated. Methylation was detected in tumors, although not in normal tissues, with the exception of two samples, indicating aberrant methylation in tumors. Clear cell carcinoma samples exhibited a higher frequency of CDKN2B promoter hypermethylation compared to those of other histological types $(\mathrm{P}=0.05)$. Our data indicate that methylation of the CDKN2B gene is a frequent event in ovarian carcinogenesis and that analysis of only three genes is sufficient to detect the presence of methylation in $35 \%$ of ovarian cancer cases. However, more studies using a much larger sample size are needed to define the potential role of DNA methylation as a marker for ovarian cancer.
\end{abstract}

\section{Introduction}

Ovarian cancer is the most lethal tumor of the female genital tract and the second most frequent gynecological cancer (1). Approximately $1.5 \%$ of females develop ovarian cancer in their lifetime. As ovarian cancer has few symptoms in its course, most cases are diagnosed in the late stages. If diagnosed during the early stages, most cases are curable. The

Correspondence to: Professor Nur Buyru, Department of Medical Biology, Istanbul University, Cerrahpasa Medical Faculty, Kocamustafapasa, 34098, Istanbul, Turkey

E-mail:nbuyru@yahoo.com

Key words: ovarian cancer, methylation, methylation-specific multiplex ligation-dependent probe amplification, tumor suppressor gene overall response rate is $80 \%$ in advanced cases. However, the 5 -year survival rate is only $15-20 \%$, mainly due to chemoresistance. Current prognostic indicators using clinicopathological variables, including stage and grade (2), neither accurately predict clinical outcome nor provide biological insight into the disease. Thus, a better understanding of the molecular mechanisms responsible for ovarian cancer development and progression is likely to aid the improvement of the diagnosis and treatment of the disease.

Similar to other tumor types, ovarian cancer is thought to arise following the activation of oncogenes and inactivation of tumor suppressor genes. In addition to genetic alterations, epigenetic abnormalities, such as changes in genomic DNA methylation patterns, are associated with all human malignancies (3-5). Changes in the DNA methylation pattern in cancer include global hypomethylation of the $\mathrm{CpG}$ dinucleotides in repetitive DNA regions (6) in conjunction with hypermethylation of $\mathrm{CpG}$ island promoter-associated genes $(3,7)$. It has been increasingly shown over the past 10 years that the $\mathrm{CpG}$ islands in the promoter regions of a large number of genes, which are mostly unmethylated in normal tissues, are methylated to varying degrees in human cancer $(4,5,7)$. Since aberrant gene methylation is one of the earliest molecular alterations occurring during cancer (8-10), it has emerged as a promising strategy for the early detection of cancer (11). In ovarian cancer, a growing number of genes have been recognized as undergoing aberrant methylation at $\mathrm{CpG}$ islands, suggesting this to be an important molecular mechanism in the development of ovarian carcinoma (12). In ovarian cancer, hypermethylation has been found to be associated with the inactivation of virtually all pathways involved in cancer development, including DNA repair, cell cycle regulation, apoptosis, cell adherence and detoxification pathways (13-20). However, most of these studies have focused on a single candidate gene and the reported frequencies and disease specificities vary between independent studies. These discrepancies most likely reflect differences in the populations that were studied and the methods used. Previous studies have suggested that methylation profiles of cancers are tumor type- and ethnicityspecific $(21,22)$.

Therefore, in the present study, we investigated aberrant methylation of promoter regions in 24 methylation-prone tumor suppressor genes in ovarian cancer tumor samples. The association between the methylation status of these genes and major clinicopathological parameters of patients was also evaluated. 


\section{Materials and methods}

Tissue samples and DNA extraction. In this study, tumor and adjacent normal tissue samples obtained from 75 ovarian cancer patients at the time of resection were used. Genomic DNA was extracted from the tissue samples of patients using the High Pure PCR template preparation kit (Roche Diagnostics, Mannheim, Germany) according to the manufacturer's instructions. This study was approved by Ethics Committee of Istanbul University, Cerrahpasa Medical Faculty (Istanbul, Turkey) and all patients provided written informed consent.

Methylation-specific multiplex ligation-dependent probe amplification (MS-MLPA). Gene methylation status was evaluated by MS-MLPA using the ME001B tumor suppressor kit (MRC-Holland, Amsterdam, The Netherlands). In this type of assay, the probes added to the samples are amplified, not sample nucleic acids. Amplification of probes by polymerase chain reaction (PCR) depends on the presence of probe-target sequences in the sample. Each probe consists of two oligonucleotides that hybridize to adjacent sites of the target sequence. The probes contain a recognition sequence for the methylation-sensitive restriction enzyme, HhaI. Upon digestion of the sample DNA probe hybrids with HhaI, unmethylated proberecognition sequences in the sample do not generate a signal. By contrast, the target region is successfully amplified if the site is methylated. The ME001 tumor-suppressor kit contains 26 probe sequences corresponding to a set of 24 tumor suppressor genes frequently silenced by methylation and 15 control probes that are not affected by methylation-sensitive HhaI restriction digestion.

Methylation determination. Following amplification, the products were analyzed by sequence type capillary electrophoresis (ABI 310; Applied Biosystems, Foster City, CA, USA). Subsequent quantification of the methylation status was performed by comparing the relative signal peaks from the digested and undigested samples. Data analysis was performed by exporting the peak areas to the excel-based Coffalyser analysis program (MRC-Holland) and the normalized areas from the digested and undigested samples were compared in order to determine the methylation status of the individual genes. Methylation was scored as positive when the calculated methylation levels were $>25 \%$. Any methylation rate below this level was regarded as background, depending on the results of negative controls and a mathematical algorithm reported previously (23).

Methylation-specific PCR (MS-PCR). The MLPA results were further confirmed by MS-PCR. Since the RASSF1 gene was one of the genes revealing the highest frequency of positivity, this gene was selected for further analysis by MS-PCR. The DNA samples were converted by sodium bisulphite using the EZ DNA Methylation Kit (Zymo Research, Irvine, CA, USA) following the manufacturer's instructions. The modified DNA was amplified using methylated- and unmethylated-specific primers to amplify the same fragment within the promoter of RASSF1. The primers were UMF: 5'-TTTGGTTGGAGTGTGTTAATGTG-3' and UMR: 5'-CAAACCCCACAAACTAAAAACAA-3' for the unmeth-
Table I. Methylation frequencies of the tumor suppressor genes in ovarian cancer.

\begin{tabular}{llc}
\hline $\begin{array}{l}\text { Tumor } \\
\text { suppressor gene }\end{array}$ & $\begin{array}{c}\text { Chromosomal } \\
\text { position }\end{array}$ & $\begin{array}{c}\text { Methylated } \\
\text { tumors, } \mathrm{n}=75(\%)\end{array}$ \\
\hline CDKN2B & $9 \mathrm{p} .21$ & $18(24)$ \\
CDH13 & $16 \mathrm{q} 24.2$ & $12(16)$ \\
RASSF1 & $3 \mathrm{p} 21.3$ & $9(12)$ \\
ESR1 & $6 \mathrm{q} 25.1$ & $6(8)$ \\
MLH1 & $3 \mathrm{p} 21.3$ & $6(8)$ \\
TIMP3 & $22 \mathrm{q} 12.3$ & $4(5.3)$ \\
APC & $5 \mathrm{q} 21$ & $4(5.3)$ \\
BRCA1 & $17 \mathrm{q} 21$ & $4(5.3)$ \\
DAPK1 & $9 \mathrm{q} 34.1$ & $3(4)$ \\
CHFR & $12 \mathrm{q} 24.33$ & $2(2.6)$ \\
IGSF4 & $11 \mathrm{q} 23$ & $2(2.6)$ \\
GSTP1 & $11 \mathrm{q} 13$ & $2(2.6)$ \\
CDKN2A & $9 \mathrm{p} 21$ & $1(1.3)$ \\
RAR $\beta$ & $3 \mathrm{p} 24$ & $1(1.3)$ \\
CASP8 & $2 \mathrm{q} 33-\mathrm{q} 34$ & $1(1.3)$ \\
VHL & $3 \mathrm{p} 26-\mathrm{p} 25$ & $1(1.3)$ \\
TP73 & $1 \mathrm{p} 36$ & $1(1.3)$ \\
ATM & $11 \mathrm{q} 22.3$ & - \\
HIC1 & $17 \mathrm{p} 13.3$ & - \\
CDKN1B & $12 \mathrm{p} 13.1$ & - \\
PTEN & $10 \mathrm{q} 23.31$ & - \\
BRCA2 & $13 \mathrm{q} 12.3$ & - \\
CD44 & $11 \mathrm{p} 13$ & - \\
FIHT & $3 \mathrm{p} 14.2$ & - \\
& & \\
& &
\end{tabular}

ylated and MF: 5'-GTGTTAACGCGTTGCGTATC-3' and MR: 5'-AACCCCGCGAACTAAAAACGA-3' for the methylated sequences. PCR was performed in a total volume of $50 \mu \mathrm{l}$ containing $100 \mathrm{ng}$ of bisulfite-converted DNA by an initial denaturation for $10 \mathrm{~min}$ at $95^{\circ} \mathrm{C}$, followed by 35 cycles of denaturation at $95^{\circ} \mathrm{C}$ for $1 \mathrm{~min}$, annealing at $60^{\circ} \mathrm{C}$ for $1 \mathrm{~min}$ and extension at $72^{\circ} \mathrm{C}$ for $1 \mathrm{~min}$. The products were analyzed on $2 \%$ agarose gels.

\section{Results}

Methylation frequencies. In this study, promoter regions from a total of 24 tumor suppressor genes were analyzed for methylation of $\mathrm{CpG}$ islands in the tumors and adjacent normal tissues of 75 ovarian cancer cases. In 17 genes, methylation was detected in at least one tumor sample. Methylation of the ATM, HIC1, CDKN1B, PTEN and FHIT genes was not detected in any tumor sample, whereas low frequencies were observed for the DAPK1 (3 samples), CHFR, IGSF4, GSTP1 (2 samples), CDKN2A, RAR $\beta$, CASP8, VHL and TP73 (1 sample) genes. Methylation frequencies ranged from $1.3 \%$ for TP73, VHL, CASP8, RAR $\beta$ and CDKN2A to $24 \%$ for CDKN2B. The most frequently methylated genes were CDKN2B (24\% of cases), CDH13 (16\% of cases) and 
Table II. Association between gene promoter methylation and clinicopathological characteristics of ovarian cancer.

\begin{tabular}{|c|c|c|c|c|c|c|c|c|}
\hline \multirow[b]{2}{*}{ Clinicopathological parameters } & \multicolumn{2}{|c|}{$\begin{array}{l}\text { CDKN2B } \\
\text { methylation }\end{array}$} & \multicolumn{2}{|c|}{$\begin{array}{c}\text { CDH13 } \\
\text { methylation }\end{array}$} & \multicolumn{2}{|c|}{$\begin{array}{c}\text { RASSF1 } \\
\text { methylation }\end{array}$} & \multicolumn{2}{|c|}{$\begin{array}{c}\text { ESR1 } \\
\text { methylation }\end{array}$} \\
\hline & + & - & + & - & + & - & + & - \\
\hline \multicolumn{9}{|l|}{ Age $(\text { years) })^{a}$} \\
\hline$\leq 50$ & 1 & 13 & 0 & 14 & 0 & 14 & 0 & 14 \\
\hline$>50$ & 7 & 16 & 3 & 20 & 0 & 23 & 4 & 19 \\
\hline \multicolumn{9}{|l|}{ Histological type } \\
\hline \multicolumn{9}{|l|}{ Epithelial ovarian tumor } \\
\hline Serous & 4 & 20 & 2 & 22 & 0 & 24 & 1 & 23 \\
\hline Mucinous & 2 & 4 & 1 & 5 & 0 & 6 & 1 & 5 \\
\hline Clear cell & 2 & 0 & 0 & 2 & 0 & 2 & 2 & 0 \\
\hline P-value & 0.0499 & & & & & & & \\
\hline Endometriosis & 0 & 1 & 0 & 1 & 0 & 1 & 0 & 1 \\
\hline Brenner & 0 & 1 & 0 & 1 & 0 & 1 & 0 & 1 \\
\hline \multicolumn{9}{|l|}{ Non-epithelial ovarian tumor } \\
\hline Granulosa cell & 0 & 4 & 0 & 4 & 0 & 4 & 0 & 4 \\
\hline \multicolumn{9}{|l|}{ Grade } \\
\hline I & 1 & 3 & 0 & 4 & 0 & 4 & 1 & 3 \\
\hline II & 2 & 8 & 2 & 8 & 0 & 10 & 1 & 9 \\
\hline III & 5 & 19 & 1 & 23 & 0 & 24 & 2 & 22 \\
\hline
\end{tabular}

${ }^{a}$ Clinicopathological data were available for 38 patients, however, information on the age of one of these patients was missing.

RASSF1 (12\% of cases). The results are shown in Table I. Overall, 30 of 75 (40\%) tumor DNA samples showed methylation at least in one gene. None of the tumor samples were methylated at $>7$ sites. Six of the 24 genes (TIMP3, CHFR, IGSF4, GSTP1, CASP8 and VHL), not previously reported to be methylated in ovarian cancer, were methylated in our study group at a low frequency (1.3-5.3\%). Two DNA samples from non-tumor tissues also showed methylation of the same genes which were methylated in the corresponding tumor tissues. This may be due to the contamination of these samples from adjacent malignant cells.

Correlation between clinicopathological characteristics and methylation. Although the initial population comprised 75 patients, reliable clinicopathological data were available only for 38 patients. Of these tumors, 34 were epithelial and 4 were non-epithelial. None of the non-epithelial tumor samples showed methylation in any of the 24 tumor suppressor genes. Hypermethylation was found in six of 24 (25\%) papillary serous, 3 of 6 mucinous $(50 \%)$ and 2 of 2 clear cell $(100 \%)$ carcinoma tumors. The remaining 2 epithelial samples also did not show methylation of any gene (Table II). To confirm the MS-MLPA results, the methylation status of the RASSF1 gene was analyzed by MS-PCR by conventional bisulfite treatment and using a commercial DNA modification kit. In all specimens, the experiments revealed identical results by MS-MLPA and MS-PCR. The clinical stage was determined according to the International Federation of Gynecology and Obstetrics (FIGO) criteria and histological subtypes were evaluated according to the World Health Organization (WHO) classification.

P-values were determined using Fisher's exact test, $\mathrm{P}<0.05$ was considered to indicate a statistically significant result. Statistical analyses of the associations between the pathological characteristics of the patients and methylation were performed for the three most frequently methylated genes. There was no association between the methylation status of the genes and tumor stage or age of the patients. Methylation of the CDKN2B gene was more frequent in clear cell carcinoma than other histological types $(\mathrm{P}=0.049)$.

\section{Discussion}

Methylation is the main epigenetic event in humans, and changes in the methylation pattern play an important role in tumorigenesis $(5,24,25)$. Early diagnosis is critical for the successful treatment of numerous types of cancer, including ovarian cancer. As aberrant methylation is frequently observed in cancer development and is thought to be one of the earliest molecular changes in carcinogenesis (26), the detection of alterations in DNA methylation patterns has potential application to the detection of early-stage or potentially premalignant disease. A specific pattern of $\mathrm{CpG}$ island hypermethylation existing in each type of human cancer was first reported for colorectal cancer by Costello et al (21) and was later confirmed by Esteller et al (27). For ovarian cancer, the methylation of different genes has been investigated in cell lines or in a small number of tumors. However, methylation of single genes may 
have limited value in clinical applications. Therefore, analysis of the methylation status of multiple genes simultaneously may provide a more sensitive and specific assay for the molecular classification and prognosis of ovarian cancer. The MS-MLPA assay is a new and sensitive method of detecting aberrant methylation in multiple genes in a single reaction (23). Therefore, in the present study the MS-MLPA method was applied to the simultaneous analysis of the methylation status of distinct tumor suppressor genes in ovarian cancer.

A large number of genes have been identified as hypermethylated and silenced in ovarian cancer, with the reported frequency of methylation varying widely between independent studies (12). Therefore the clinical relevance of these observations remains uncertain. In 2001, Strathdee et al (19) reported that primary ovarian cancer may exhibit multiple methylator phenotypes, including known tumor suppressor genes. In previous studies, the most frequenty methylated genes were reported as the OPCML, Hsulf-1, GATA4, DAPK1 and CDH13 genes $(12,15,16,28-30)$. In agreement with these reports, the most frequently methylated genes in our study were the CDKN2B, CDH13 and RASSF1 genes. CDKN2B is a cell cycle control gene and several lines of evidence indicate that variants of these genes, particularly CDKN2A, are crucial in ovarian cancer (31-33). Results of a recent study have indicated that the underexpression of certain cell cycle regulatory proteins, such as CDKN2A, is a predictive marker for shorter overall survival in ovarian carcinoma (34). In most cases, loss of the protein occurs due to the deletion of the gene (35). Yang et al also investigated methylation in gynecological cancers and reported that BRCA1, p14, p16 and PTEN are differentially silenced by hypermethylation (36). However, certain investigators have also suggested that CDKN2B does not have an important role in ovarian carcinogenesis, due to the absence of mutations and homozygous deletion of the gene in ovarian cancer (37). In contrast to CDKN2A, the methylation and mRNA expression of CDKN2B in ovarian cancer have not been extensively investigated. Aberrant methylation in the promoter region of the gene has been found in a number of types of cancer, including hematological malignancies (38-40) and lung (41) and breast cancer (42). The reported rates of CDKN2B methylation in ovarian cancer tissue ranges from 0 to $30.8 \%(18,37,43)$. One study indicated that methylation of CDKN2B was present in 30.8\% (43) of ovarian cancer cases and was associated with disease progression, whereas other studies showed that methylation of CDKN2B is a rare event $(18,37)$. The discrepancies among these results may be due to the differences in methods for methylation detection, inclusion of different histological types or the differences in the ethnic origins of the patients. However, in our study, CDKN2B was the most frequently methylated gene among 24 tumor suppressor genes. Our results are comparable to those reported by Kudoh et al (32) and Liu et al (43). However, we found a statistically borderline correlation between CDKN2B methylation and clear cell carcinoma. Clear cell tumors are generally regarded as the most aggressive histological type of epithelial tumors. In our study, all the clear cell carcinoma samples showed methylation of the CDKN2B gene promoter. Our results indicate that the CDKN2B gene is silenced in ovarian cancer, and especially in clear cell carcinoma, by promoter methylation instead of deletion or mutation.
However, the number of patients with clear cell carcinoma was low $(2.6 \%)$ in our study group.

CDH13 was the second most frequently methylated gene in our study group. CDH13 (H-cadherin) is a cell adherence protein and the loss of CDH13 expression in malignant ovarian tumors has been reported previously (44). Although hypermethylation of CDH13 is common in breast and lung cancer (45), there are only a few reports in the literature investigating CDH13 methylation in ovarian cancer $(15,16,44,46)$. According to these studies, $\mathrm{CDH} 13$ has been found to be methylated in 13-67\% of ovarian cancer tissue samples. Although it was the second most frequently methylated gene in our study group, the methylation frequency was not as high as previously reported (46). This difference may reflect population differences, since epigenetic alterations may be different in different ethnic groups. Our results support the role of the CDH13 gene in ovarian cancer.

The third most frequently methylated gene was RASSF1. RASSF1 is a tumor suppressor gene, the inactivation of which is suggested in the development of different types of human cancer (47). Although it may be inactivated by deletion or point mutations, the most common contributor to loss or reduction of RASSF1 function is transcriptional silencing of the gene by inappropriate promoter methylation. Previous studies have indicated that RASSF1 is frequently methylated in breast, lung and ovarian cancers $(42,48,49)$. Although there are conflicting reports in the literature with regard to the methylation of the RASSF1 gene in ovarian tumors, our results are in agreement with the findings of Agathanggelou et al (49), which showed that RASSF1 is methylated in $10 \%$ of ovarian cancer cases, irrespective of grade. In this study, no statistically significant association was found between RASSF1 hypermethylation and clinicopathological characteristics, such as age, tumor grade and the histological tumor type.

We observed a lower degree of hypermethylation (1.3-8\%) in the promoters of 14 genes, which act in different cellular pathways. These results indicate that in ovarian cancer, several genes which have a role in different pathways may be silenced by promoter hypermethylation.

\section{Acknowledgements}

The present study was supported by the Research Fund of Istanbul University, Project No. 2834.

\section{References}

1. Jemal A, Siegel R, Ward E, Murray T, Xu J and Thun MJ: Cancer statistics. CA Cancer J Clin 57: 43-66, 2007.

2. Clark TG, Stewart ME, Altman DG, Gabra H and Smyth JF: A prognostic model for ovarian cancer. Br J Cancer 85: 944-952, 2001.

3. Baylin SB and Herman JG: DNA methylation in tumorigenesis: epigenetics joins genetics. Trends Genet 16: 168-174, 2000.

4. Jones PA: DNA methylation errors and cancer. Cancer Res 56: 2463-2467, 1996.

5. Jones PA and Laird PW: Cancer epigenetics comes of age. Nat Genet 21: 163-167, 1999

6. Wilson AS, Power BE and Molloy PL: DNA hypomethylation and human diseases. Biochem Biophys Acta 1775: 138-162, 2007.

7. Jones PA: The DNA methylation paradox. Trends Genet 15: 34-37, 1999.

8. Lund $\mathrm{AH}$ and van Lohuizen M: Epigenetics and cancer. Genes Dev 18: 2315-2335, 2004. 
9. Laird PW: Cancer epigenetics. Hum Mol Genet 14: R65-R76, 2005.

10. Ducasse $M$ and Brown MA: Epigenetic aberrations and cancer. Mol Cancer 5: 60, 2006.

11. Paluszczak J and Baer-Dubowska W: Epigenetic diagnostics of cancer - the application of DNA methylation markers. J Appl Genet 47: 365-375, 2006.

12. Barton CA, Hacker NF, Clark SJ and O'Brien PM: DNA methylation changes in ovarian cancer: implications for early diagnosis, prognosis and treatment. Gynecol Oncol 109: 129-139, 2008.

13. Swisher EM, Gonzalez RM, Taniguchi T, Garcia RL, Walsh T, Goff BA and Welcsh P: Methylation and protein expression of DNA repair genes: association with chemotherapy exposure and survival in sporadic ovarian and peritoneal carcinomas. Mo Cancer 8: 48, 2009.

14. Ibanez de Caceres I, Battagli C, Esteller M, Herman JG, Dulaimi E, Edelson MI, Bergman C, Ehya H, Eisenberg BL and Cairns P: Tumor cell-specific BRCA1 and RASSF1A hypermethylation in serum, plasma and peritoneal fluid from ovarian cancer patients. Cancer Res 64: 6476-6481, 2004.

15. Makarla PB, Saboorian MH, Ashfaq R, Toyooka KO, Toyooka S, Minna JD, Gazdar AF and Schorge JO: Promoter hypermethylation profile of ovarian epithelial neoplasms. Clin Cancer Res 11: 5365-5369, 2005

16. Rathi A, Virmani AK, Schorge JO, Elias KJ, Maruyama R, Minna JD, Mok SC, Girard L, Fishman DA and Gazdar AF: Methylation profiles of sporadic ovarian tumors and nonmalignant ovaries from high-risk women. Clin Cancer Res 8: 3324-3331, 2002

17. Yuecheng Y, Hongmei L and Xiaoyan X: Clinical evaluation of E-cadherin expression and its regulation mechanism in epithelial ovarian cancer. Clin Exp Metastasis 23: 65-74, 2006.

18. Tam KF, Liu VW, Liu SS, Tsang PC, Cheung AN, Yip AM and Ngan HY: Methylation profile in benign, borderline and malignant ovarian tumors. J Cancer Res Clin Oncol 133: 331-341, 2007.

19. Strathdee G, Appleton K, Illand M, Millan DW, Sargent J, Paul J and Brown R: Primary ovarian carcinomas display multiple methylator phenotypes involving known tumor suppressor genes. Am J Pathol 158: 1121-1127, 2001.

20. Kiwerska K, Rydzanicz M, Kram A, Pastok M, Antkowiak A, Domagala W and Szyfter K: Mutational analysis of CDKN2A gene in a group of 390 larynx cancer patients. Mol Biol Rep 37: 325-332, 2010 .

21. Costello JF, Frühwald MC, Smiraglia DJ, Rush LJ, Robertson GP, Gao X, Wright FA, Feramisco JD, Peltomäki P, Lang JC, Schuller DE, Yu L, Bloomfield CD, Caligiuri MA, Yates A, Nishikawa R, Su Huang H, Petrelli NJ, Zhang X, O'Dorisio MS, Held WA, Cavenee WK and Plass C: Aberrant CpG-island methylation has non-random and tumour-type-specific patterns. Nat Genet 24: 132-138, 2000.

22. Mehrotra J, Ganpat MM, Kanan Y, Fackler MJ, McVeigh M, Lahti-Domenici J, Polyak K, Argani P, Naab T, Garrett E, Parmigiani G, Broome C and Sukumar S: Estrogen receptor/ progesterone receptor-negative breast cancers of young AfricanAmerican women have a higher frequency of methylation of multiple genes than those of Caucasian women. Clin Cancer Res 10: 2052-2057, 2004.

23. Nygren AO, Ameziane N, Duarte HM, Vijzelaar RN, Waisfisz Q, Hess CJ, Schouten JP and Errami A: Methylation-specific MLPA (MS-MLPA): simultaneous detection of $\mathrm{CpG}$ methylation and copy number changes of up to 40 sequences. Nucleic Acids Res 33: e128, 2005.

24. Warnecke PM and Bestor TH: Cytosine methylation and human cancer. Curr Opin Oncol 12: 68-73, 2000.

25. El-Osta A, Baker EK and Wolffe AP: Profiling methyl-CpG specific determinants on transcriptionally silent chromatin. Mol Biol Rep 28: 209-215, 2001

26. Jones PA and Baylin SB: The fundamental role of epigenetic events in cancer. Nat Rev Genet 3: 415-428, 2002.

27. Esteller M, Corn PG, Baylin SB and Herman JG: A gene hypermethylation profile of human cancer. Cancer Res 61: 3225-3229, 2001.

28. Sellar GC, Watt KP, Rabiasz GJ, Stronach EA, Li L, Miller EP, Massie CE, Miller J, Contreras-Moreira B, Scott D, Brown I, Williams AR, Bates PA, Smyth JF and Garba H: OPCML at 11q25 is epigenetically inactivated and has tumor-suppressor function in epithelial ovarian cancer. Nat Genet 34: 337-343, 2003.

29. Teodoridis JM, Hall J, Marsh S, Kannall HD, Smyth C, Curto J, Siddiqui N, Gabra H, McLeod HL, Strathdee G and Brown R: $\mathrm{CpG}$ island methylation of DNA damage response genes in advanced ovarian cancer. Cancer Res 65: 8961-8967, 2005.
30. Wakana K, Akiyama Y, Aso T and Yuasa Y: Involvement of GATA-4/5 transcription factors in ovarian carcinogenesis. Cancer Lett 241: 281-288, 2006.

31. Milde-Langosch K, Ocon E, Becker G and Löning T: p16/MTS1 inactivation in ovarian carcinomas: high frequency of reduced protein expression associated with hyper-methylation or mutation in endometrioid and mucinous tumors. Int J Cancer 79: 61-65, 1998.

32. Kudoh K, Ichikawa Y, Yoshida S, Hirai M, Kikuchi Y, Nagata I, Miwa M and Uchida K: Inactivation of p16/CDKN2 and p15/ MTS2 is associated with prognosis and response to chemotherapy in ovarian cancer. Int J Cancer 99: 579-582, 2002.

33. Schildkraut JM, Moorman PG, Bland AE, Halabi S, Calingaert B, Whitaker R, Lee PS, Elkins-Williams T, Bentley RC, Marks JR and Berchuck A: Cyclin E overexpression in epithelial ovarian cancer characterizes an etiologic subgroup. Cancer Epidemiol Biomarkers Prev 17: 585-593, 2008.

34. Lee YH, Heo JH, Kim TH, Kang H, Kim G, Kim J, Cho SH and An HJ: Significance of cell cycle regulatory proteins as malignant and prognostic biomarkers in ovarian epithelial tumors. Int $\mathrm{J}$ Gynecol Pathol 30: 205-217, 2011.

35. Drexler HG: Review of alterations of the cyclin-dependent kinase inhibitor INK4 family genes p15, p16, p18 and p19 in human leukemia-lymphoma cells. Leukemia 12: 845-859, 1998.

36. Yang HJ, Liu VW, Wang Y, Tsang PC and Ngan HY: Differential DNA methylation profiles in gynecological cancers and correlation with clinico-pathological data. BMC Cancer 6: 212, 2006.

37. Fujita M, Enomoto T, Haba T, Nakashima R, Sasaki M, Yoshino K, Wada H, Buzard GS, Matsuzaki N, Wakasa K and Murata Y: Alteration of p16 and p15 genes in common epithelial ovarian tumors. Int J Cancer 74: 148-155, 1997.

38. Dodge JE, Munson C and List AF: KG-1 and KG-1a model the p15 CpG island methylation observed in acute myeloid leukemia patients. Leukemia Res 25: 917-925, 2001.

39. Aggerholm A, Guldberg P, Hokland M and Hokland P: Extensive intra- and interindividual heterogeneity of p15INK4B methylation in acute myeloid leukemia. Cancer Res 59: 436-441, 1999.

40. Herman JG, Jen J, Merlo A and Baylin SB: Hypermethylationassociated inactivation indicates a tumor suppressor role for p15INK4B. Cancer Res 56: 722-727, 1996.

41. Wang Y, Zhang D, Zheng W, Luo J, Bai Y and Lu Z: Multiple gene methylation of nonsmall cell lung cancers evaluated with 3-dimensional microarray. Cancer 112: 1325-1336, 2008.

42. Buyru N, Altinisik J, Ozdemir F, Demokan S and Dalay N: Methylation profiles in breast cancer. Cancer Invest 27: 307-312, 2009.

43. Liu Z, Wang LE, Wang L, Lu KH, Mills GB, Bondy ML and Wei Q: Methylation and messenger RNA expression of p15INK4b but not p16INK4a are independent risk factors for ovarian cancer. Clin Cancer Res 11: 4968-4976, 2005.

44. Kawakami M, Staub J, Cliby W, Hartmann L, Smith DI and Shridhar V: Involvement of $\mathrm{H}$-cadherin $(\mathrm{CDH} 13)$ on $16 \mathrm{q}$ in the region of frequent deletion in ovarian cancer. Int $\mathrm{J}$ Oncol 15: 715-720, 1999 .

45. Toyooka KO, Toyooka S, Virmani AK, Sathyanarayana UG, Euhus DM, Gilcrease M, Minna JD and Gazdar AF: Loss of expression and aberrant methylation of the CDH13 (H-cadherin) gene in breast and lung carcinomas. Cancer Res 61: 4556-4560, 2001.

46. Wu Q, Lothe RA, Ahlquist T, Silins I, Tropé CG, Micci F, Nesland JM, Suo Z and Lind GE: DNA methylation profiling of ovarian carcinomas and their in vitro models identifies HOXA9, HOXB5, SCGB3A1, and CRABP1 as novel targets. Mol Cancer 6: 45,2007 .

47. Dammann R, Schagdarsurengin U, Seidal C, Strunnikova M, Rastetter M, Baier K and Pfeifer GP: The tumor suppressor RASSF1A in human carcinogenesis: an update. Histol Histopathol 20: 645-663, 2005.

48. Yoon JH, Dammann R and Pfeifer GP: Hypermethylation of the CpG island of RASSF1A gene in ovarian and renal cell carcinomas. Int J Cancer 94: 212-217, 2001.

49. Agathanggelou A, Honorio S, Macartney DP, Martinez A, Dallol A, Rader J, Fullwood P, Chauhan A, Walker R, Shaw JA, Hosoe S, Lerman MI, Minna JD, Maher ER and Latif F: Methylation associated inactivation of RASSF1A from region 3 p21.3 in lung, breast and ovarian tumors. Oncogene 20: 1509-1518, 2001 